\title{
Thomas Heywood, Just in Time
}

Grace Ioppolo

Early Theatre 17.2 (2014), 122-132

DOI: http://dx.doi.org/10.12745/et.17.2.1209

\begin{abstract}
The scholarly study of the dramatic works and career of Thomas Heywood has increased significantly in the last fifty years but still lags far behind that of his contemporaries Shakespeare and Jonson. Labelled the 'prose Shakespeare' by Charles Lamb in the early nineteenth century, Heywood seems to have been considered by scholars and publishers to be a ghostly figure who haunted the early modern theatrical world. In fact, recent research using archival records shows the ways in which Heywood was at the centre of an extensive and highly networked professional industry.
\end{abstract}

The scholarly attention shown to the life, career, and works of Thomas Heywood in post-doctoral monographs, editions, articles, book chapters, and conference papers has noticeably increased in the last ten years. Using the MLA Bibliography to examine the patterns in annual figures of publications on Heywood demonstrates why Heywood finally finds himself becoming much more central to early modern drama and theatre studies. ${ }^{1}$

Behind these figures are some interesting trends. First, there appears to be a kind of cyclical nature to an increase in Heywood publications, with 1986, 1994, 2000, 2002, 2005, and 2007 showing spikes upward, followed by some decline for a few years. It may be that publishers and journal and book editors have treated Heywood as a 'token' who was allowed his share of attention every few years amidst overpopulated Shakespeare studies.

The single Heywood work that had seen the largest share of critical attention is A Woman Killed with Kindness, which has become the best known and most frequently performed of Heywood's plays. Critics seem to preface their comments on the play by calling it Heywood's 'masterpiece', but whether it is the best of his plays is debatable, given that many scholars seem only to have read that play and no other Heywood work and are satisfied that it is the best of his canon without further investigation. Judging from the frequency of publication on this play only from the late 1950s, A Woman Killed with

\footnotetext{
Grace Ioppolo (g.j.ioppolo@reading.ac.uk) is professor of Shakespearean and early modern drama in the department of English literature at the University of Reading, and founder and director of The Henslowe-Alleyn Digitisation Project (www.henslowe-alleyn.org.uk).
} 
Kindness appears to owe much of its modern critical popularity to the rise of gender studies beginning in the 1960s. Heywood's plays about women, including The Fair Maid of the West, have skewed the study of his works so that he has become central to the study of gender in historical context, especially from the 1970s, but has sometimes languished in terms of other theoretical applications. Yet his other female-titled plays The Wise Woman of Hoxton, The Fair Maid of the Exchange, The Rape of Lucrece, and A Maidenhead Well Lost, as well as his three prose histories of notable women (England's Elizabeth, her Life and Troubles, Gynaikeion, or, Nine Books of Various History Concerning Women, and The Exemplary Lives and Memorable Acts of Nine the Most Worthy Women of the World) have received less critical attention, especially in terms of gender studies.

Beyond the gender-specific studies of The Fair Maid of the West and A Woman Killed with Kindness, scholarly publications from 1907 to 2013 show studies of a range of Heywood's plays and occasional or one-off study of his pageants, masques, prose works, poems, and translations. Also included are more general studies of his sources, influences, and main themes, as well as the transmission of his texts, including manuscript and printing-house studies, largely due to the survival of two autograph manuscripts of entire plays, The Captives and Calisto, or The Escapes of Jupiter, and his autograph contributions to the collaborative play Sir Thomas More, originally written by Anthony Munday and seemingly endlessly added to by others, including Chettle, Dekker, and Shakespeare. Heywood's copious comments over many years in printed advertisements, prefaces, and epilogues to his works allow him not only to pinpoint his involvement in the transmission of his works from author to playhouse to theatrical and reading audiences but also to create and re-create his own identity as author and to define and re-define concepts of early modern authorship. Yet Heywood has received only scant attention in the twentieth- and twenty-first-century theoretical or bibliographic discussions of the life or even the death of the author unless he is invoked in sometimes controversial studies of Shakespeare as a collaborator rather than as a sole author of particular plays. ${ }^{2}$

The pages of Henslowe's Diary that record Heywood's frequent collaboration with other canonical playwrights can place him at the centre of attribution studies of early modern drama. Hence we especially have scholarly publications on Heywood from the beginning of the New Bibliography in the early twentieth century that apply specific theories about Heywood's composition and revision practices and the consequences for textual transmission 
more generally to his sometime collaborators, most notably Shakespeare. Heywood's contributions to early modern theatre history in terms of playing companies and playhouses are also represented in publications, and these publications occasionally recognize his part in the use of theatre performance and production to create contemporary English identity and history. Heywood collaborated or worked with the major dramatists, actors, company managers, and theatre owners of the period, including Henslowe, Alleyn, Shakespeare, Munday, Chettle, Middleton, Dekker, Jonson, Fletcher, Webster, Rowley, Beeston, and Brome. That he began writing in the 1590s and continued well into the 1630s, although apparently taking a hiatus from writing plays from 1614 to $1624,{ }^{3}$ gave him an appreciably longer career under three monarchs and courts, and much wider political, cultural, and religious perspectives, than most of his contemporaries. Even in the last decade of his life, Heywood's ever-expanding network of patrons was financially successful, ${ }^{4}$ reminding us of the way in which his career until 1641 helped bridge pre- and post-Restoration concepts of drama and performance. In a real sense, Heywood should be considered as the first early modern theatre historian, as 'he was familiar with all the playwrights from 1596 to 1642 , besides possessing trustworthy information about those who had died before he came to London'. ${ }^{5}$ He used this information to create collaborative playwright and playhouse networks that we have not yet begun to appreciate.

Although the annual scholarly publication numbers on Heywood may look paltry compared to those of Shakespeare and even Jonson in the same years, Heywood struggled against a major stumbling block not faced by these two contemporaries: his works have not been available in either a seventeenth- or a twentieth-century collected edition, while Shakespeare's and Jonson's collected works were available in both centuries. Most of Heywood's long prose tracts, translations, and poems have been out of print for over 300 years, as have many of the plays, masques, and pageants of which he was the sole author or a collaborator. For this rather large obstacle, we could blame Heywood himself, who claimed in 1632 that a collection of his works was in progress but who admitted one year later that the project had been abandoned. ${ }^{6}$ Modern scholars who published on Heywood's canon were often limited to using rare physical books before the advent of Early English Books Online. But even after the availability of this electronic resource, EEBO far too often offered smeared and sometimes illegible facsimiles, requiring a great deal of patience and time, two luxuries not often available to publish-or-perish academics who need a very quick turnover time from the 
submission of a manuscript to its appearance in physical print. Working on Heywood may not have been as time-efficient or career-productive as working on Shakespeare, Jonson, Dekker, Beaumont and Fletcher, and other early modern dramatists whose entire canons have been available at least for a few decades in excellent critical editions. Nor was it particularly rewarding or glamorous to work on Heywood, given the lack of knowledge of his canon by non-specialists and the general ignorance of his contributions to early modern drama and theatre.

The annual publication figures may also suggest that Heywood indeed remained a necessarily arcane, privileged, or 'token' subject, so that particular Heywood scholars occasionally trained new generations of Heywood scholars, who continued to publish and to train new scholars, and hence there is a notable increase in PhD dissertations in the 1960s when post-doctoral Heywood studies seemed to be burgeoning. In the very crowded field of early modern English drama studies, finding something wholly original to say about Heywood has been much easier than doing the same with Shakespeare, Jonson, Marlowe, and even Middleton, and thus MA and PhD students looking for thesis or dissertation subjects may have been steered, probably quite reluctantly, towards Heywood. Once steered, they do not seem to have stayed the course, as many of those publishing on Heywood moved on to his more famous and more highly-rated contemporaries, judging from the lack of second publications on Heywood by many of the scholars included in these annual figures. In over three decades of attending scholarly conferences, I do not recall meeting more than a few people who declared that they were Heywood specialists, although I have encountered well over a thousand who claim Shakespeare's works as their specialism.

Writing a dissertation on Heywood most likely brings its own problems post PhD: being considered for an entry-level early modern drama position at a college or university as a non-Shakespearean drama specialist is more difficult than being hired as a Shakespearean, judging from recent years of job ads in North America and the United Kingdom. Given Shakespeare's unique status, hiring committees may still assume that candidates who publish primarily on Shakespeare can cover any undergraduate and graduate drama courses but may not seem so readily convinced that a Heywood specialist can cover Shakespeare and his other contemporaries or even drama of other periods. Thus, not surprisingly, while there is an ever-expanding membership of the Shakespeare Association of America, which offers some non-drama seminars and panels at its conferences, there is no international 
Jonson or Heywood counterpart society. The Marlowe Society holds conferences, albeit small, only every five years. As Louis B. Wright noted almost a hundred years ago, although a few of Heywood's plays were performed after the Restoration and into the eighteenth century, his importance was only reestablished in the nineteenth century by Charles Lamb and William Hazlitt. Yet, Lamb's praise of Heywood as the 'prose Shakespeare' really did not do all that much to help Heywood's reputation on his own terms, especially in the twentieth century. ${ }^{7}$

Several of Heywood's collaborators and contemporaries have received full editorial treatment in modern times, including: Dekker (Cambridge University Press, 4 volumes, 1953-61); Chapman (University of Illinois Press, 2 volumes, 1970-87); Massinger (Oxford University Press, 5 volumes, 1976); Beaumont and Fletcher (Cambridge University Press, 10 volumes, 196696); Webster (Cambridge University Press, 3 volumes, 1995-2008); Jonson (Clarendon Press, 11 volumes, 1925-52; Cambridge University Press, 7 volumes, 2012); Middleton (Oxford University Press, 2007); Brome (online at http://www.hrionline.ac.uk/brome/ and in progress for paper publication by Oxford University Press); Shirley (in progress, http://www2.warwick .ac.uk/fac/arts/ren/oupjamesshirley/); and Ford (Oxford University Press, in progress). Even though Jean E. Howard recently offered a vigorous defense of Heywood's innovative career and his significance as an early modern dramatist, her essay appeared in The Cambridge Companion to Shakespeare and Contemporary Dramatists, in which Heywood did not even rate a mention in the book's title in $2012 .{ }^{8}$ Scholars can fully understand the production and performance of early modern English drama only by having online and/or print access to Heywood's considerable canon.

As Heywood's plays were not printed in a collected edition in his lifetime, assembling his canon proves much more troublesome than for Jonson and Shakespeare whose canons were established in folios in 1616 and 1623. Heywood's disingenuous claim, 'It neuer was any great ambition in me, to bee in this kind Voluminously read', ${ }^{9}$ does not really suggest that he had a 'suspicion of print', ${ }^{10}$ as his shrewd comments in his printed works about his profession (or perhaps vocation) show his skill at manipulating print for a variety of reasons. Rather than a fear of print, he probably had a fear of seeming embarrassed by the lack of being printed. He knew what print could and could not do for or to him.

The first and only collected edition of his plays, The Dramatic Works of Thomas Heywood, produced in 1874 in six volumes by R.H. Shepherd, 
has long been out of print, consigning Heywood's canon to library shelves stocked with dusty nineteenth-century volumes (no longer an attractive place for many students or young scholars). G. Blakemore Evans's collected edition, announced in 1948, never appeared, but what a magnificent edition that would have been, judging from his superb editorial work in The Riverside Shakespeare. Some individual plays by Heywood have been edited in the last fifty years in the Revels, New Mermaid, Regents' Renaissance Drama, and other series, and feature in the Arden non-Shakespearean editions now being produced. Many of Heywood's works, however, will still remain out of print and, apparently, out of mind.

But as I noted above, in the last ten years, scholars have increasingly recognized the importance of Heywood's plays and unique commentaries on acting and stage-craft, and his works have become central to post-graduate study in drama of this period. Although especially celebrated for his city comedies, Heywood was proficient in tragedy and tragic-comedy. Notably, he was innovative in addressing issues of gender, including the social and cultural effects of a female monarch on a traditionally patriarchal society. In addition, Heywood was recognized in his own time as a master essayist, an accolade he shared with no other playwright of his time. In his treatises, pamphlets, and broadsides, he 'dissected' and 'anatomized', to use his own terms, the religious and political dilemmas of contemporary monarchs and their courts. As principal writer of pageants for the Lord Mayor's Day from 1631 to 1639, Heywood was in a unique position to celebrate civic governance and local policy and to satirize them in other forms and genres. He also produced and circulated translations of ancient Greek and Latin texts, as well as writing his own poetry. Uniquely, he served as the editor and often the literary critic of the plays and poems of his collaborators and contemporaries, often describing in detail how these texts were transmitted from author to audience. His portions of Sir Thomas More show him reworking portions of texts by integrating insertions and deletions by other collaborators, and what is most striking is that he seems insistent on the integrity of the text as a whole, not on his own self-promotion in the text, a role that would have been easy to take up as the text's final arbiter at various points.

The launch of the Henslowe-Alleyn Digitisation Project (www.henslowe -alleyn.org.uk), which I founded and direct, has made freely available online over 2000 pages of the Philip Henslowe-Edward Alleyn papers in which Heywood figures prominently as an all-encompassing man of the theatre. Heywood was the only major playwright who served as a 'covenanted' actor 
to Henslowe, which required Heywood to work with Henslowe alone for two years, ${ }^{11}$ signifying Heywood's probably exceptional skill at playing. His graduation to major playwright and collaborator among the companies with which Henslowe and later Alleyn worked suggests a strong bond among the three men. Heywood's career with Henslowe may have been preceded by a place in the earl of Southampton's acting company, if we can trust Heywood's claim in an elegy upon the death of James I that Heywood had 'once' been Southampton's servant. ${ }^{12}$ Heywood's other activities as recorded in Henslowe's Diary show him to be closely involved with the production of his plays other than simply as playwright. For example, on behalf of Worcester's Men, on 3 February 1602/3, Henslowe paid a tailor 22 shillings 'for velluet $\&$ satten for the womon gowne of black veluett with the other lyneges belonginge to it' and the next day reimbursed Heywood $£ 6$ and 13 shillings 'for A womones gowne of black veluett for the playe of A womon kylled with kyndness'. A few days later, on 12 February, Henslowe apparently gave Heywood his first payment of $£ 3$ for the play, giving the final payment of $£ 3$ on 6 March $1602 / 3 .{ }^{13}$ That Henslowe, on behalf of Worcester's Men, paid a tailor more for the leading character's gown than he paid Heywood for the play does not seem to have bothered Heywood. Instead, these entries suggest that Heywood was already concerning himself with the costume for his main character a month before the play was even finished, and that he had taken it upon himself to deal with the majority of the payment to the tailor, with Henslowe paying the small remainder. Thus Heywood probably told the tailor exactly how he wanted his heroine, Anne Frankford, to be dressed.

We could assume that Shakespeare did the same as a shareholder and chief playwright for the Lord Chamberlain's and later the King's Men, but we doubtless would never have considered this possibility without these Heywood records. So perhaps Shakespeare was as involved with Rosalind's doublet and Desdemona's dress as Heywood was with Anne's black velvet gown. Heywood's concern for costume, and perhaps other features of his play in production, was probably not extraordinary for an early modern playwright. As a man who collaborated with so many other playwrights and moved so seamlessly, and apparently genially, if we accept his colleagues' praise in the preface to An Apology for Actors, between companies and playhouses, we should assume that Heywood's supervision of even the minor details of his plays in performance was not unusual.

Thus rather than seeing Heywood as the prose equivalent of someone else, those of us involved in this modern collected edition of his works dedicate 
ourselves to making Heywood accessible in his own right to students, scholars, general readers, actors, and directors, and to establishing him as a major and seminal contributor to early modern English drama, poetry, and prose, the same roles he held in his own lifetime. Our edition will do something we consider unique: we are producing an old-spelling edition of the works in electronic form only and a modern-spelling edition in print and electronic form. These plans required a great deal of negotiation with the OUP editorial board, which for some time insisted that we do the old-spelling edition in print. But as argued by our editing team, including those trained by scholars who insisted on the principles of the New Bibliography for single and collected editions, Heywood would become even more obscure and inaccessible to modern readers and audiences in an old-spelling print format, which is especially incompatible with the rise of social and digital media. We want Heywood to be mainstreamed, not marginalized (again), and to be available in editions that could easily be used in the theatre, as well as the classroom. Without a doubt, Heywood needs to be modern, not antiquarian.

But early on we faced yet one more problem in convincing OUP that we could cope with Heywood and that was in deciding what belonged in his canon. Rather than spend endless years working on attribution (as one reader of our OUP proposal seemed to imply that we do), we trusted the judgment of one of our editing team: MacDonald P. Jackson, who had already largely sorted out where we should place Heywood in terms of collaborative plays. Thus we could form a canon in which Heywood was the sole author or a main collaborator of plays, and we are including plays that have much more than Heywood's 'maine finger' and instead have both his hands, so to speak.

Only about one quarter of Heywood's 220 works survive in print or manuscript form. All of his own plays, including those co-written with other dramatists, as well as his poetry and prose, are being freshly edited from the editions published during his lifetime. Heywood's manuscripts of The Escapes of Jupiter and The Captives in his own hand, as well as additions and revisions in his own hand within Sir Thomas More, give us a full sense of how he wrote. Scribal manuscripts are extant for his The Art of Love and for the play Dick of Devonshire latterly attributed to him. Most of his plays exist in quartos, which allow us to compare spelling with that in his autograph manuscripts. Thus we have a canon for our edition. We have organized his works chronologically within genres (plays, poetry, prose), with four to six plays per volume. I am providing a biographical and critical general introduction for 
volume one, and each editor will provide a critical and textual introduction for each work, discussing its date, sources, language and style, dramaturgy, and theatrical history, as well as full textual notes and glosses. Rather than assigning an editor to one play only, our team of editors, including Susan Anderson, Peter Beal, Marliss Desens, Barry Gaines, MacDonald P. Jackson, David Lindley, William B. Long, Paul Mulholland, Matteo Pangallo, Marion O'Connor, Lena Cowen Orlin, Alison Shell, and William Proctor Williams, have each agreed to edit multiple works. Our volumes are comprised in this way:

\section{Volume 1: Plays}

Introduction: Heywood and his Works; Edward IV, Parts 1 \& 2; If You Know Not Me, You Know Nobody, Parts 1 \& 2; The Four Prentices of London.

\section{Volume 2: Plays}

The Fair Maid of the Exchange; $A$ Woman Killed with Kindness; The Rape of Lucrece; The Fair Maid of the West, Parts $1 \& 2$.

\section{Volume 3: Plays}

The Golden Age; The Silver Age; The Brazen Age; The Iron Age, Parts 1 \& 2.

\section{Volume 4: Plays and Theatrical Contexts}

Sir Thomas More; The Captives; The Escapes of Jupiter, or Calisto; Dick of Devonshire; An Apology for Actors.

\section{Volume 5: Plays}

The English Traveller; A Maidenhead Well Lost; A Challenge for Beauty; The Royal King and the Loyal Subject.

\section{Volume 6: Late Plays, Masques, and Pageants}

The Wise Woman of Hoxton; The Late Lancashire Witches; Fortune by Land and Sea; Love's Mistress, or The Queen's Masque; Londini Artium \& Scientiarum Scaturigo; Londini Emporia; Londini Sinus Salutis; Londini Status Pacatus; London's Ius Honorarium; Londini Speculum.

\section{Volume 7: Poetry}

A Funeral Elegy upon the death of Prince Henry; A marriage triumph solemnized in an Epithalamium; A Funeral Elegy, upon the death of King 
James; Oenone and Paris; The Art of Love; Troia Britanica, or Great Britain's Troy; Pleasant Dialogues and Dramas; Preparative to Study or the virtue of sack; Reader, here you'll plainly see; Life and Death of Queen Elizabeth.

\section{Volume 8: Prose Pamphlets}

The Phoenix of these Late Times; A Dialogue or Accidental Discourse; Judgement perverted; The Three Wonders of this Age, The Wonder of this Age; A true Description of His Majesty's Royal Ship; A True Discourse of the Two Infamous upstart Prophets; A True Relation of the Lives and Deaths of the two most Famous English Pirates; The Life of Merlin, His prophecies and predictions interpreted; Machiavel, as he lately appeared to his dear Sons the Modern Projectors; Philocothonist, or The Drunkard Opened, Dissected and Anatomised.

\section{Volume 9: Early Prose Histories}

England's Elizabeth, her Life and Troubles; The Hierarchy of Angels.

\section{Volume 10: Later Prose Histories}

The Гvvalkelov [Gynaikeion]: or, Nine Books of Various History concerning Women; The exemplary Lives and memorable Acts of nine the most worthy Women of the world.

We have made Heywood's plays our first priority so that he can return to the stage, if not make his first foray into Hollywood films, as Wright wished in 1928 (see the Introduction, 120), as soon as possible. In fact, Wright was not the only scholar writing on Heywood in the early twentieth century who tinged his comments with expressions of regret. For example, in 1923, E.K. Chambers called the loss of Heywood's Lives of All the Poets Moderne and Forreigne, begun around 1614 and never finished or published in any form, 'irreparable.' ${ }^{14}$ If Heywood had finished it, just think what he might have told us about Shakespeare and Jonson, not to mention himself, demonstrating that this 'ghost' needs to start speaking up again. 
I32 Issues in Review

\section{Notes}

1 By year, the number of publications is: $2013: 10 ; 2012: 8 ; 2011: 7 ; 2010: 7 ; 2009: 12$; 2008: 6; 2007: 15; 2006: 7; 2005: 13; 2004: 10; 2003: 7; 2002: 16; 2001: 8; 2000: 10; 1999: 5; 1998: 6; 1997: 5; 1996: 4; 1995: 8; 1994: 11; 1993: 4; 1992: 3; 1991: 1; 1990: 5; 1989: 6; 1988: 3; 1987: 2; 1986: 9; 1985: 1; 1984: 5; 1983: 6; 1982: 3; 1980: 5; 1979: 1; 1978: 3; 1977: 7; 1976: 5; 1975: 7; 1974: 7; 1971: 3; 1970: 6; 1969: 5; 1968: 5; 1967: 8; 1966: 1; 1965: 4; 1963-4: 1 each year; 1962: 5; 1961: 6; 1960: 2; 1959: 3; 1958: 4; 1957: 3; 1956: 3; 1955: 5; 1954: 1; 1951-2: 1 each year; 1950: 3; 1949: 1; 1945-46: 2 each year; 1943-44: 1 each year; 1941: 1; 1936-9: 1 each year; 1931: 2 ; 1930: 3; 1928: 5; 1927: 3; 1926: 1; 1925: 1; 1924: 2; 1922: 1; 1919: 1; 1918: 2; 1913: 2; 1910: 1; 1907: 1 .

2 See, for example, Brian Vickers', Shakespeare, Co-Author (Oxford, 2002), in which he examines various twentieth-century authorship and attribution controversies.

3 G.E. Bentley, The Jacobean and Caroline Stage, 7 volumes (Oxford, 1941-68), 4: 556.

4 David Bergeron, 'Patronage of Dramatists: The Case of Thomas Heywood', English Literary Renaissance 18 (1988), 294-304.

5 Arthur Melville Clark, 'Thomas Heywood as a Critic', Modern Language Notes 37 (1922), 223. For the best discussion of Heywood's career and canon, see Bentley, The Jacobean and Caroline Stage, 4:553-86.

6 For the cultural and literary consequences of this abandonment, see Benedict Scott Robinson, 'Thomas Heywood and the Cultural Politics of Play Collections', Studies in English Literature 42 (2002), 361-80.

7 See Louis B. Wright, 'Notes on Thomas Heywood's Later Reputation', The Review of English Studies, 4 (1928), 141.

8 Jean E. Howard, 'Thomas Heywood: Dramatist of London and Playwright of the Passions', Ton Hoenselaars (ed.), The Cambridge Companion to Shakespeare and Contemporary Dramatists (Cambridge, 2012), 120-33.

9 Heywood, 'To the Reader', The English Traveller (London: Robert Raworth, 1633; ESTC S104058), A3r.

10 See Robinson, 'Thomas Heywood and the Cultural Politics of Play Collections', 365.

11 R.A. Foakes and R.T. Rickert (eds), Henslowe's Diary (Cambridge, 1961), 241.

12 Charles A. Rouse postulates that Heywood could have been a member of a company patronized by Southampton either before 1598 or between 1600 and 1602. However, given that Southampton was implicated in Essex's rebellion against Elizabeth I in February 1601, and was not back in court favour until the accession of James I in 
early March 1603 in 'Was Heywood a Servant of the Earl of Southampton?' PMLA 45 (1930) 787-90,, Southampton could not have been patronizing a company of actors between February 1601 and March 1603. This fact means that Heywood's association with Southhampton was most likely prior to 1598 and probably before May 1596, the first time that Henslowe pays him for a play.

13 Foakes and Rickert, Henslowe's Diary, 223-4. For digital images of the original manuscript pages, see http://www.henslowe-alleyn.org.uk/images/MSS-7/119v.html and http://www.henslowe-alleyn.org.uk/images/MSS-7/120r.html.

14 E.K. Chambers, The Elizabethan Stage, 4 vols (Oxford, 1923), 3:339. 